\title{
The Implications of Intellectual Property Rights in Protecting Animal Genetics Resources and Biodiversity: A Review
}

\author{
R. Selvam* \\ Department of Animal Genetics and Breeding, Veterinary College \\ and Research Institute, Tirunelveli - 627 358, Tamil Nadu, India \\ Tamil Nadu Veterinary and AnimalSciences University \\ *Corresponding author
}

\section{Keywords}

Intellectual Property

Rights, Patent,

Biological Diversity

Act, traditional

knowledge, sui

generis system

Article Info

Accepted:

05 June 2020

Available Online:

10 July 2020

\section{A B S T R A C T}

The objective of this review is to summarize the importance of various forms of intellectual property rights, impacts of PBR, CBD, TRIPS and Biological Diversity Act 2002 and future prospects in protecting the native livestock breeds and associated traditional knowledge for conservation and their sustainable use in the modern IPR system. Intellectual Property Rights is an exclusive right over the creations of the mind. Intellectual property includes patents, trademarks, industrial designs and geographical indications and copyright. IPR rewards the creativity and it encourages economic growth. PBR is a sui generis system for protecting plants. India is signatory to CBD and TRIPS Agreement, it is obligatory for India to develop suitable legislation to protect and improve livestock genetic resources and associated traditional knowledge. As a member to the UN Convention on Biological Diversity, India formulated the Biological Diversity Act, 2002. The effects of IPRs on animal genetic resources and biodiversity diversity are rarely been evaluated, but there is an imperative need for this analysis. Protection of native livestock breeds and associated traditional knowledge through appropriate sui generis system is essential for conservation and their sustainable use in the modern IPR system. The internationally accepted legal system is must be developed in relation to the use of livestock biodiversity.

\section{Introduction}

Intellectual property (IP) refers to creations of the mind which includes inventions, literary and artistic works, and symbols, names, images, and designs used in commerce. Intellectual property is divided into two categories such as Industrial Property includes patents for inventions, trademarks, industrial designs and geographical indications (WIPO, 1970). Intellectual Property Rights (IPR) is an exclusive right over the creations of the mind. Intellectual property includes patents, trademarks, industrial designs and geographical indications and copyright (Groombridge, 1992). The IP rights are outlined in Article 27 of the Universal Declaration of Human Rights, which provides 
for the right to benefit from the protection of moral and material interests follow-on from authorship of scientific, literary or artistic productions. The treaties administered by the World Intellectual Property Organization such as Paris Convention for the Protection of Industrial Property (1883) and the Berne Convention for the Protection of Literary and Artistic Works (1886) distinguished the importance of intellectual property (WIPO, 1970). The objective of this review is to summarize the importance of various forms of intellectual property rights, impacts of Plant Breeders' Rights, CBD, TRIPS and Biological Diversity Act 2002 and future prospects in protecting the native livestock breeds and associated traditional knowledge for conservation and their sustainable use in the modern IPR system.

The reasons for promote and protect intellectual property are

IPR give creators exclusive rights to their creations, thereby providing an incentive for the author or inventor to develop and share the information rather than keep it secret.

The legal protection of new creations encourages the commitment of additional resources for further innovation.

The promotion and protection of intellectual property encourages economic growth, creates new jobs and industries, and enhances the quality and enjoyment of life.

An efficient intellectual property system can help all countries to realize intellectual property's potential as a catalyst for economic development and social and cultural well-being.

The intellectual property system helps strike a balance between the interests of innovators and the public interest, providing an environment in which creativity and invention can flourish, for the benefit of all.

IPR enhances the value and profitability of a business. It signifies a certain standard, method or competitive edge and lays the groundwork for maximizing on the commercial results of its ownership (Sharma, 2014).

\section{Patent}

Patent is exclusive right given to the inventor for his invention, it represents a legal monopoly granted by the respective country's government to an inventor (specific to a geographic region. Patent protection means that the invention cannot be commercially made, used, distributed or sold without the patent owner's consent. These patent rights are usually enforced in a court, which, in most systems, holds the authority to stop patent infringement. Conversely, a court can also declare a patent invalid upon a successful challenge by a third party. A patent owner has the right to decide who may - or may not - use the patented invention for the period in which the invention is protected. The patent owner may give permission to, or license, other parties to use the invention on mutually agreed terms. The owner may also sell the right to the invention to someone else, who will then become the new owner of the patent. Once a patent expires, the protection ends, and an invention enters the public domain, that is, the owner no longer holds exclusive rights to the invention, which becomes available to commercial exploitation by others.

Patents provide incentives to individuals by offering them recognition for their creativity and material reward for their marketable inventions. These incentives encourage innovation, which assures that the quality of human life is continuously enhanced. Patents must meet certain criteria which include non- 
obviousness or the inventive step which requires that there be a real invention and not a simple result from some obvious extension of existing technology. Novelty, which refers to something created that is new and utility or usefulness of the invention. Patents may be related to a process, a product produced by a process. In animal sciences, patent can be granted for a product (gene sequence, protein), process and research tool (receptors or antibodies, apparatus (PCR machine). Technologies in animal breeding that qualify for IP protection include statistical methods, DNA markers, methods to measure traits, methods to identify animals and computer software (Ramesha et al., 2010, Matthew Rimmer, 2008). Diamond vs. Chakrabarty law case open the ways for patenting of higher forms of life. First animal patent is for "Onco mouse" by Harvard University (1984). (Lessor, 2002 and Rothschild, 2002). In India, Patents are granted for products or processes that are novel, useful, and in respect of which an inventive step can be demonstrated.

\section{The following are considered as non- patentable inventions}

1. Plant variety

2. Animal species

3. Any part of a plant or an animal [including seeds]

4. Essential biological processes

5. Traditional knowledge component or a group of components

6. Methods of treatment of animals either to increase their value or to increase the value of the derivable products of that animal

7. Methods of treating the animals to make them disease resistant etc.,

8. Bioinformatics

9. Any inventions which may be frivolous, against to the established natural laws, affecting the plant or animal life or the environment
10. Discoveries of scientific principles and thermos

11. Inventions related to obscenity (any statement or act which strongly offends the prevalent morality of the time)

12. A method of agriculture and horticulture

\section{The patentable inventions}

1. Genetically modified microorganisms

2. Nucleotide sequences and Amino acid sequences

3. Methods of extraction of bioactive compounds from plant or animal kingdoms.

4. Methods of making the disease resistant, drought resistant plant varieties

5. Processes of making the genetically modified plants with desirable characters.

6. Herbal extracts and methods of obtaining them

7. Cultures and methods of culturing and Nutrition mediums etc.,

\section{Copyrights}

Copyrights are another form of IP which is used to protect IP that includes articles, books, softwares and also music. In general, copyrights involve limited formal procedures. In many cases the creative work can be copyrighted by simply adding the symbol, but registering the mark provides formal legal protection.

\section{Trademark}

Trademarks are used to protect the identifications of source of the owners' goods, products or services and it can be informal (simply using TM) or formally registered (®). Trademarks applied to specific products that 
are required to be from a certain origin and have a specific level of quality (Lesser, 2002).

For example a specific pork product from Berkshire is protected by the trademark "Berkshire Gold ${ }^{\text {TM" }}$ and PICmarq $^{\text {TM }}$ suggestive of gene marker which used in selection of pigs by PIC organization. (Nebel et al., 2002).

\section{Trade secret}

A trade secret represents IP that is not revealed by the owner and therefore confers some competitive advantage. Trade secrets have no time limits. For examples the specific information to make specialized synthetic lines or specialized selection programs, indexes and seed stock are protected under Trade secret.

\section{Plant breeders' rights (PBR)}

PBR is a special system for protecting plants. In most countries, PBR are administered by an office of the agriculture department, rather than by a separate patent office. Since it is exclusive for plants it is a form of sui generis or special-purpose system administered by the UPOV (the French acronym for the International Convention for the Protection of New Varieties of Plants) established on 1961. PBRs replace utility, non-obviousness and novelty for patent systems with uniformity, stability, distinctness and novelty (FAO, 2005).

\section{CBD, TRIPS and biological diversity act 2002}

At the international level, the two major agreements governing access and rights over genetic resources are Convention on Biological Diversity (CBD) of United Nations and Trade Related Aspects of Intellectual Property (TRIPs) Agreement of World Trade
Organization. India is signatory to both CBD and TRIPs. Hence there is a need to assess the issues at hand with a global perspective and also narrate and evaluate the options for the typical livestock production situation existing in the country (Bhat, 2009). India also approved the Global Plan of Action on Animal Genetic Resources.

Therefore, it is obligatory for India to develop suitable legislation to protect and improve livestock genetic resources and associated traditional knowledge. As a member to the UN Convention on Biological Diversity, India formulated the Biological Diversity Act, 2002 which provides that the authority to determine access to genetic resources. IPR issues related to biodiversity protection and conservation in India are currently managed under the Biodiversity Act, 2002.

The conservation of biological diversity, continues use of its components and equitable sharing of the benefits arising out of the use of biological resources and knowledge are the main objectives of the Biological Diversity Act 2002. Under TRIPS, provision is made for plant variety protection under patents or a sui generis system, or a combination of both but there is no similar system for animals. Under TRIPS neither prior informed consent nor protection of TK is mandated. TRIPS also do not offer sufficient recourse for balancing the rights of the owners of AnGR (Ramesha, 2011).

Livestock keepers' have the risk of losing their intellectual property rights, while biotechnology firms require a legal framework to operate. Thus, there is an urgent need for internationally recognized legally binding instrument which gives right to livestock keepers including rights over associated indigenous traditional knowledge (Damodaran, 2008). 


\section{Bioprospecting and biopiracy}

Bioprospecting is the exploration, extraction and screening of biodiversity and traditional knowledge for commercially valuable genetic and biochemical resources. Frequently, the term bioprospecting refers to the use of traditional knowledge in finding leads for pharmaceutical research. Biopiracy is thieving of knowledge from traditional and indigenous population or persons. An example for Biopiracy is the unique genetic quality of high milk fat content ranging from 6.02 to 7.86 per cent of Indian dwarf cattle breed 'Vechur'. Roslin Institute and the PPL Therapeutics (Scotland) Ltd have 14 patent applications at the European Patent Office and one of these (EP 0765390) for the gene construct of bovine alpha-lactalbumin. So there is an immediate need for biodiversity rich countries like India topromote bioprospecting and to prevent biopiracy (Ramesha et al., 2008).

\section{Need for a sui generis system for animal genetic resources}

In spite of significant contribution of animals to the food security and nutrition, laws and policies including intellectual property protection on genetic resources at the national as well as international level so far has focused only at plant genetic resources. There is a need for legally binding internationally accepted system for access and sharing of benefits from the use of AnGR and associated traditional knowledge.

There is a need for recognition of community rights over knowledge and biodiversity. Considering the special characteristics of AnGR it is essential to develop a suitable sui generi system for AnGR for protection of intellectual property rights (Ramesha et al., 2010). In case of animal breeding most of the cases superior individual animal or its germplasm is more important than providing protection for a breed/ variety. The major problem lies in identifying characteristics that could be used as a standard description of the subject matter. Breed associations and herd book registration will help in breed conservation and intellectual property protection (Verrier, 2005). A sui generis system linked to special geographical related characteristics of the animals or their products aimed at preventing misappropriation of AnGR and associated knowledge held by livestock keepers needs to be developed. Livestock keepers' rights could include production and grazing rights as well as protection of traditional knowledge.

\section{Need for an international treaty on animal genetic resources}

In the modern biotechnology era, there is danger of animal genetic material from biodiversity rich countries being exploited by others, including large international companies. The development of a legal binding 'International Framework on Animal Genetic Resources' is therefore, a matter of urgency (http://dad.fao.org) on Animal Genetic Resources held at Switzerland delegates from 109 countries including India adopted a Global Plan of Action for Animal Genetic Resources, the first internationally agreed framework to halt the erosion of livestock diversity and support the sustainable use, development and conservation of animal genetic resources." In future, IP protection is likely to influence pricing and international trade of livestock products in a significant way. Livestock keepers' have the risk of losing their intellectual property rights, while biotechnology firms require a legal framework to operate. Thus, there is an urgent need for internationally recognized legally binding instrument which gives right to livestock keepers including rights over associated indigenous traditional knowledge (FAO, 2004 and Rothschild, 2002). 
Development and diffusion of knowledge intensive technologies in all livestock sector are greatly influenced by IPR system. Among various types of IPR, patents, trademarks, trade secrets and geographical indications are relevant to the livestock sector. Each of these forms of IPR has different requirements and grants different legal status. The full scope of patent protection in the field of animal breeding has not yet been determined.

The application of patents to this field of innovation is fairly recent, and there is a need for more in-depth analysis of the probable consequences of introducing patents to animal breeding. Several observations are need to be made on how the special field of animal breeding calls for adaptation of the general patent laws to this particular field of technology.

Patent has been identified as a major tradable asset of enormous importance in the modern knowledge regime. Patent law has potential to alter the existing legal conditions for competition and investments in the field of animal breeding, and needs therefore a higher level of awareness among policy-makers, animal breeders and farmers.

The effects of IPRs on animal genetic resources, genetic diversity, genetic improvement and the livelihoods of livestock keepers have scarcely been analysed, but are in urgent need of exploration. Protection of native livestock breeds and associated traditional knowledge through appropriate sui generis system is essential for conservation and their sustainable use in the modern IPR system.

The internationally accepted legal system is need to be developed with respect to use of livestock biodiversity, then the IPR in animal sciences will bring economic benefit to the livestock keepers.

\section{Potential patentable areas in animal} sciences

There are unique traits in the native farm livestock species of Indian subcontinent, which can be harnessed or exploited through biotechnologies. The distinctive attributes of breeds can be exploited for profits by getting some form of Intellectual Property Rights or protection.

The notable areas for IPRs could be the following in Indian context.

Superior disease resistance.

Adaptation to withstand tropical heat and far greater climatic fluctuations.

Better potentials to utilize coarse quality feed and fodder resources.

Better survivability under more recurrent drought conditions.

Superior growth and higher fecundity in some species / breeds.

Potential to yield of certain unique products, which have economic potential after value addition.

Therapeutic and nutritional value of certain livestock products.

Geographical application of breeds associated with traits or products.

Indigenous technical knowledge on animal husbandry.

Utilization of unique genes through biotechnologies for novel use.

With further advances in biotechnologies and processing techniques, many more IPR relevant areas would emerge.

\section{References}

Bhat Ishwara, P., (2009). The Role of Collective bodies in protection of intellectual property rights in India. Journal of Intellectual Property Rights, 14: 214-225. 
Damodaran, A., (2008). Traditional Knowledge, Intellectual Property Rights and Biodiversity conservation; Critical issues and Key Challenes. Journal of Intellectual Property Rights, 13: 509513.

FAO, (2004). Report by the Commission on Genetic Resources for Food and Agriculture on the Intergovernmental Technical Working Group on Animal Genetic Resources for Food and Agriculture, Food and Agriculture Organization of the United Nations, Rome.

FAO, (2005). The legal framework for the management of animal genetic resources. FAO Legislative Study. ISBN 978-82-7613-504-6, 1-33.

Groombridge, B., (1992). Intellectual property rights for biotechnology. In Global biodiversity: Status of the Earth's living resources, 495-99. London: Chapman and Hall.

Lesser, W., (2002) In "Intellectual Property rights and Patenting in Animal Breeding and Genetics" Editors M.F. Rothschild and S. Newman, CAB International, axon UK, 1-16.

Matthew Rimmer, (2008). Intellectual Property and Biotechnology: Biological Inventions. Edward Elgar Publishing.

Nebel, H., Akrad, L., and Brady, T., (2002).

"Intellectual Property Rights in Animal Breeding and Genetics" Editors M.F.
Rothschild and S. Newman, CABI, axon, UK pg 119-146.

Ramesha, K. P., (2011). Intellectual Property Rights Regime for Livestock Agriculture in India-Present Status and Future Prospects. Journal of Intellectual Property Rights, 16: 154-162.

Ramesha, K. P., Pourouchottamane, R. and Bhattacharya, M., (2010). Intellectual property rights-Animal genetic resources-Options for India. Indian Dairyman, 62: 50-63.

Ramesha, K. P., Pourouchottamane, R., Kataktalware, M. A. and Sarkar, M., (2008). Intellectual Property Rights (IPR) issues in livestock biodiversityIndian Perspective. Journal of Livestock Biodiversity. 1: 8-12.

Rothschild Max and Scott Newman, Intellectual Property Rights in Animal Breeding and Genetics. CABI publishing 2002.

Sharma, D. K., (2014). Intellectual property and the need to protect it. Indian Journal of Scientific Research. 9: 084087

Verrier, E., Tixier-Boichard, M., Bernigaud, R. and Naves, M., (2005). Conservation and value of local livestock breeds: usefulness of niche products and/or adaptation to specific environments. Animal Genetic Resources Information. 36.

\section{How to cite this article:}

Selvam. R. 2020. The Implications of Intellectual Property Rights in Protecting Animal Genetics Resources and Biodiversity: A Review. Int.J.Curr.Microbiol.App.Sci. 9(07): 140-146. doi: https://doi.org/10.20546/ijcmas.2020.907.016 